\title{
Effect of Hydrothermal Processing on Colour, Antioxidant and Free Radical Scavenging Capacities of Edible Irish Brown Seaweeds
}

\author{
Gaurav Rajauria \\ Technological University Dublin, gaurav.rajauria@tudublin.ie \\ Amit Jaiswal \\ Technological University Dublin, amit.jaiswal@tudublin.ie \\ Nissreen Abu-Ghannam \\ Technological University Dublin, nissreen.abughannam@tudublin.ie
}

See next page for additional authors

Follow this and additional works at: https://arrow.tudublin.ie/schfsehart

Part of the Food Chemistry Commons, Food Microbiology Commons, and the Food Processing

Commons

\section{Recommended Citation}

Abu-Ghannam, N. et al. (2010) Effect of hydrothermal processing on colour, antioxidant and free radical scavenging capacities of edible Irish brown seaweeds. International Journal of Food Science \&

Technology, 45(12), 2485-2493. doi: 10.1111/j.1365-2621.2010.02449.x

This Article is brought to you for free and open access by the School of Food Science and Environmental Health at ARROW@TU Dublin. It has been accepted for inclusion in Articles by an authorized administrator of ARROW@TU

Dublin. For more information, please contact arrow.admin@tudublin.ie, aisling.coyne@tudublin.ie, gerard.connolly@tudublin.ie.

Funder: Irish government under the Technological Sector Research Scheme (Strand III) of the National Development Plan

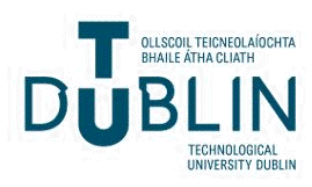




\section{Authors}

Gaurav Rajauria, Amit Jaiswal, Nissreen Abu-Ghannam, and Shilpi Gupta

This article is available at ARROW@TU Dublin: https://arrow.tudublin.ie/schfsehart/40 


\title{
Original article
}

\section{Effect of hydrothermal processing on colour, antioxidant and free radical scavenging capacities of edible Irish brown seaweeds}

\author{
Gaurav Rajauria, Amit K. Jaiswal, Nissreen Abu-Ghannam* \& Shilpi Gupta \\ Department of Food Science, School of Food Science and Environmental Health, Dublin Institute of Technology, Cathal Brugha Street, Dublin 1, \\ Ireland
}

(Received 13 April 2010; Accepted in revised form 14 July 2010)

\begin{abstract}
Summary The effect of heat processing on change in colour $(\Delta \mathrm{E})$, level of bioactive compounds and overall antioxidant capacity in raw and heat-processed edible Irish brown seaweeds was investigated. Raw seaweeds were heated at $85-121^{\circ} \mathrm{C}$ for $15 \mathrm{~min}$ in an autoclave and extracted with $60 \%$ methanol. In comparison with raw seaweeds for all the species studied, heating increased total phenol (TPC) (1.6- to 1.9-fold) and total tannin (TTC) (1.3- to 2.6-fold) at $95{ }^{\circ} \mathrm{C}$, while total flavonoid (TFC) (1.6- to 3.3-fold) and total sugar (TSC) (1.9- to 4.3 -fold) at $85^{\circ} \mathrm{C}$. Similarly, $\mathrm{EC}_{50}$ value reduced in case of $\mathrm{DPPH}^{\circ}$ scavenging $(30.7-51.8 \%)$, metal chelating ability (FIC) (27-67.8\%) and $\mathrm{H}_{2} \mathrm{O}_{2}$ scavenging capacity $(13.3-16.1 \%)$ at $95{ }^{\circ} \mathrm{C}$, while reduction in lipid peroxidation (10.8-31.5\%) observed at $85{ }^{\circ} \mathrm{C}$. Results showed that heating affects content of bioactive compounds as well as beneficial biological activity associated with these compounds, which can suggest new processing for application of seaweeds extract as nutraceutical.
\end{abstract}

Keywords Antioxidant capacity, heat processing, Irish brown seaweeds, phytochemical content.

\section{Introduction}

The traditional role of antioxidants, as their name suggests, deals mainly with inhibiting the development of oxidative rancidity in fat-based foods. Oxidation, or the loss of an electron, can sometimes produce reactive oxygen species, which include free radicals (e.g. superoxide anion radical $\left(\mathrm{O}_{2}^{-}\right)$, hydroxyl radicals $\left(\mathrm{OH}^{\bullet}\right)$, hydrogen peroxide $\left(\mathrm{H}_{2} \mathrm{O}_{2}\right)$, singlet oxygen $\left.\left({ }^{1} \mathrm{O}_{2}\right)\right)$ and free transition metal ions (Halliwell \& Gutteridge, 1999). These can cause oxidative stress or damage to the cellular biomolecules such as DNA, proteins and lipids. Biomolecules degradation in turn can cause accelerated ageing and many chronic diseases, including cancer, cardiovascular diseases, inflammation and some neurological disorders (Finkel \& Holbrook, 2000). Antioxidants are capable of stabilising these free radicals before they can react and cause harm; they also prevent neurodegenerative disorders by scavenging the free radicals and delaying or preventing oxidation of the above-mentioned molecules. Because oxidation is a naturally occurring process within the human body, a balance with antioxidants must exist to maintain health;

*Correspondent: Fax: + 353 14024411;

e-mail: nissreen.abughannam@dit.ie therefore, antioxidants are becoming an increasingly important ingredient in food processing.

A major trend in the food industry, driven by consumer concerns, has been the shift from the use of synthetic ingredients to natural bioactive compounds in food products. As a consequence, there has been a huge interest to identify natural antimicrobials and antioxidants with multifunctional potential as alternatives for synthetic ingredients to prevent oxidation and spoilage in complex food systems (Wang et al., 2009). Towards the development of safe and improve the quality of products, a new class of food products, called 'functional food', has found great success in the market. A food can be functional if, besides its nutritious effect, it has demonstrated benefits for one or more functions for the humans, improving the state of health or reducing the risk of disease (Diplock et al., 1999). There are a wide range of compounds that are used or could be potentially employed as functional ingredients, such as polyphenols polysaccharides, polyunsaturated fatty acids and other antioxidant pigments (Plaza et al., 2008).

Marine macroalgae, commonly known as seaweeds, are potential renewable resource in the marine habitat. Seaweeds constitute about 6000 species, with a great diversity of forms, size and are present in complex environmental conditions like change of salinity, temperature, nutrients, radiations and combination of light 
and high oxygen concentration (Chandini et al., 2008). These seaweeds must therefore, be able to adapt rapidly to the new environmental conditions to survive, producing a great variety of secondary metabolite compounds, which cannot be found in terrestrial plants. These secondary metabolites such as polyphenols (phlorotannins, fucoxanthin, flavonoids) and polysaccharides (fucoidan, laminarans) have preventive effect on cerebrovascular diseases, show anticoagulating activity and help in increasing metabolism and reducing obesity. (MacArtain et al., 2007; Plaza et al., 2008).

Ireland has a great diversity of seaweeds because its location between 51 and $55^{\circ} \mathrm{N}$, occupying a range of latitude that overlap both the northern limit for some warm-water species and the southern limit for some cold-water species. Over 500 species of seaweeds (274 red, 147 brown and eighty green species) from Irish coasts have been identified (Morrissey et al., 2001), although the production is small, at around 32000 tones compared to the annual global production figure of 15.1 million tonnes (Campbell, 2007); however, limited information is available on the antioxidant activity and beneficial effects of their bioactive compounds. Brown algae, well-known commercially important seaweeds in Ireland, are found from high on the intertidal to well below the lowest tides. These edible brown seaweeds are attracting increasing attention as a valuable food source because of its high nutritional value when compared to land plants (MacArtain et al., 2007). Asian countries like China and Japan utilise seaweeds as a raw material in processed food, meat, dairy products and domestic commodities. Thermal processing is mainly applied not only for purpose of food preservation but also to increase the edibility, digestibility and bioavailability of nutrients and phytochemicals in foods. In another previous study, we demonstrated that hydrothermal processing of edible Irish brown seaweeds significantly removes the surface microflora with a reduction in antimicrobial activity (Gupta et al., 2010). However, it has long been perceived that thermally processed food, fruits and vegetables have altered nutritional value than fresh produce because of variation in some physiochemical characteristics. Therefore, with this fact in mind, this study aims at evaluating the effect of heat processing on phytochemical constituents, free radical scavenging capacity and antioxidant potential using methanolic extracts of three species of raw and hydrothermally treated (autoclaved) edible Irish brown seaweeds.

\section{Materials and methods}

\section{Chemicals}

All the chemicals and reference compounds were purchased from Sigma-Aldrich Chemical Co. (Steinheim, Germany).

\section{Seaweed material and processing}

Brown seaweeds used in this study were Laminaria saccharina, Laminaria digitata and Himanthalia elongata. They were purchased from Quality Sea Veg., Co Donegal, Ireland. Samples were washed thoroughly to remove epiphytes, sand and debris and stored at $-18{ }^{\circ} \mathrm{C}$ until analysis. Seaweed $(5 \mathrm{~g})$ was added to $100-\mathrm{mL}$ flask containing $25 \mathrm{~mL}$ deionised water and autoclaved (Tomy SS-325; Tomy Seiko Co. Ltd. Tokyo, Japan) at a range temperatures; 85, 95, 100, 110 and $121{ }^{\circ} \mathrm{C}$ for $15 \mathrm{~min}$. After cooling, water was decanted and seaweeds were crushed with liquid nitrogen and extracted according to the existing method in our laboratory, with $60 \%$ methanol (Gupta et al., 2010). All the dried methanolic extracts were dissolved in water, and a concentration of $1000 \mathrm{ppm}$ was used for phytochemical analysis. Raw seaweeds were used as control against the different heat processing temperatures studied.

\section{Instrumental colour analysis}

The Hunter Lab co-ordinates $\left[L^{*}\right.$ (lightness), $a^{*}$ (redgreen) and $b^{*}$ (yellow-blue)] were measured by a spectrocolorimetre (ColorQuest XE, Hunter associate laboratory, Inc. Reaston VA) and a CIE standard illuminant C. Hunter lab colour metre was calibrated using black and white references. Colour was studied using the $L^{*}, a^{*}$ and $b^{*}$ Hunter scale parameters.

The total amount of colour change to see the effect of heat was calculated as per equation 1 (Silva \& Silva, 1999).

$$
\Delta E=\sqrt{\left(L_{o}-L\right)^{2}+\left(a_{o}-a\right)^{2}+\left(b_{o}-b\right)^{2}}
$$

where $\mathrm{L}_{0}, \mathrm{a}_{0}$ and $\mathrm{b}_{0}$ are the colour parameters of raw seaweeds. This total change takes into account the change in each of the colours described by the $L^{*}, a^{*}$ and $b^{*}$ parameters and may be more applicable than the three colour parameters individually for evaluating the effect of heat on seaweeds.

\section{Phytochemical analysis}

Total phenolic content (TPC)

The amount of total phenolic content in the crude methanolic extract was determined using Folin-Ciocalteau's phenol reagent (Taga et al., 1984). The TPC of the seaweeds was expressed as $\mathrm{mg}$ gallic acid equivalents (GAE)/g dry weight (dw) extract.

Total flavonoid content (TFC)

The TFC was determined by a colourimetric method described by Liu et al. (2009). TFC was expressed as mg quercetin equivalents $(\mathrm{QE}) / \mathrm{g}$ extract $(\mathrm{dw})$. 
Total condensed tannin content (TTC)

Condensed tannins were determined by a spectrometric method described by Liu et al. (2009). (+)-Catechin was used as a reference compound, and results were expressed as $\mathrm{mg}(+)$-catechin equivalents $(\mathrm{ChE}) / \mathrm{g}$ extract $(\mathrm{dw})$.

\section{Total sugar content (TSC)}

Total sugars were estimated by phenol-sulphuric acid method with minor modifications (Dubois et al., 1956). Briefly, an aliquot of $100 \mu \mathrm{L}$ of sample or standard was taken with water $(1: 1, \mathrm{v} / \mathrm{v})$ and $100 \mu \mathrm{L}$ of phenol solution $(0.8 \%, \mathrm{w} / \mathrm{v})$ were added and mixed well. Finally, $2 \mathrm{~mL}$ of concentrated $\mathrm{H}_{2} \mathrm{SO}_{4}$ were added and allowed to stand at room temperature for $10 \mathrm{~min}$. After that, the samples were incubated in water bath for $20 \mathrm{~min}$ at $30{ }^{\circ} \mathrm{C}$, and absorbance recorded at $490 \mathrm{~nm}$. The results were expressed as $\mathrm{mg}$ glucose equivalent $(\mathrm{GlcE}) / \mathrm{g}$ extract (dw).

\section{Antioxidant analysis}

$D P P H$ radical scavenging assay

This assay was carried out as described by Yen \& Chen (1995), with some modifications. Briefly, the assay was performed in a 96-well round-bottom microplate with $1: 1$ ratio of $100 \mu \mathrm{L}$ of DPPH radical solution $(165 \mu \mathrm{M})$ and $100 \mu \mathrm{L}$ of sample. Different concentrations were tested for each sample to get $\mathrm{EC}_{50}$ value. The reaction mixtures were incubated for $30 \mathrm{~min}$ at $25^{\circ} \mathrm{C}$ in dark conditions, and absorbance measured at $517 \mathrm{~nm}$ in a microplate reader (Powerwave, Biotek, Winooski, VT, USA). The ability to scavenge the DPPH radical was calculated using the following equation:

$$
\begin{aligned}
& \text { Scavenging capacity }(\%)= \\
& {\left[1-\left(\frac{\mathrm{A}_{\text {sample }}-\mathrm{A}_{\text {sample blank }}}{\mathrm{A}_{\text {control }}}\right)\right]}
\end{aligned}
$$

where $A_{\text {control }}$ is the absorbance of the control (DPPH solution without sample), $A_{\text {sample }}$ is the absorbance of the test sample (DPPH solution plus test sample) and $A_{\text {sample blank }}$ is the absorbance of the sample only (sample without any DPPH solution). Calculated $\mathrm{EC}_{50}$ values indicate the concentration of sample required to scavenge $50 \%$ DPPH radicals. The lower the $\mathrm{EC}_{50}$ value of the sample, the higher the antioxidant capacity.

\section{Metal ion chelating ability assay}

The chelating ability of ferrous ion (FIC) by raw and processed brown seaweeds was estimated by the original method of Decker \& Welch (1990) with minor modifications. This assay is based upon the formation of bluecoloured ferrous ion-ferrozine complex that has a maximum absorbance at $562 \mathrm{~nm}$. Briefly, $100 \mu \mathrm{L}$ of varying concentrations of different extract samples and standard were mixed with $100 \mu \mathrm{L}$ of deionised water and $25 \mu \mathrm{L}$ of ferrous chloride $(0.5 \mathrm{mM})$ in a microplate. The reaction was initiated by the addition of $25 \mu \mathrm{L}$ of ferrozine $(2.5 \mathrm{~mm})$, and the reaction mixture was shaken vigorously. The absorbance was recorded at $562 \mathrm{~nm}$ with a microplate reader, after $10 \mathrm{~min}$ of incubation at ambient temperature. EDTA was used as a standard compound. The percentage of inhibition of ferrozine$\mathrm{Fe}^{2+}$ complex formation was calculated using eqn (2).

\section{Lipid peroxidation in a haemoglobin-induced linoleic acid system ( $L P O$ )}

The antioxidant activity was principally determined by a photometry assay reported by Kuda et al. (2005) with slight modifications, which is based upon the degree of inhibition of the haemoglobin-catalysed peroxidation of linoleic acid. The samples $(100 \mu \mathrm{L})$ of raw, processed seaweeds and standard were mixed in a test tube together with $25 \mu \mathrm{L}$ of $0.1 \mathrm{M}$ linoleic acid/ethanol and $75 \mu \mathrm{L}$ of $0.2 \mathrm{M}$ phosphate buffer ( $\mathrm{pH} 7.2)$. The autooxidation of linoleic acid in the above-mentioned reaction mixture was initiated by adding $50 \mu \mathrm{L}$ haemoglobin $(0.08 \%$ in water) and incubated for $60 \mathrm{~min}$ at $37^{\circ} \mathrm{C}$. The peroxidation of linoleic acid was stopped by adding $5 \mathrm{~mL}$ of $\mathrm{HCl}(0.6 \%$ in ethanol). The value of peroxidation of samples in the reacted mixture was calculated using the ferric thiocyanate method, in which colour appeared upon addition of $50 \mu \mathrm{L}$ of ferrous chloride $(20 \mathrm{~mm})$ and ammonium thiocyanate $(30 \%)$ each, in that order. For the estimation of peroxide value, $200 \mu \mathrm{L}$ of the above-mentioned coloured reacted mixture $\left(\mathrm{A}_{\text {sample }}\right)$ was taken in triplicate in a microplate, and absorbance was recorded at $490 \mathrm{~nm}$ using a microplate reader (Powerwave, Biotek, VT, USA). Ascorbic acid was used as standard. The antioxidant capacity (AOC) of the samples was calculated using eqn (2).

\section{Hydrogen peroxide $\left(\mathrm{H}_{2} \mathrm{O}_{2}\right)$ scavenging assay}

The hydrogen peroxide scavenging capacity of raw and heat-processed seaweeds was estimated by the method of Ruch et al. (1989). The concentration of hydrogen peroxide was determined spectrophotometrically (Agilent 8453 with PDA detector, Waldbronn, Germany) by measuring absorption with molar extinction coefficient for $\mathrm{H}_{2} \mathrm{O}_{2}$ of $43.6 \mathrm{M}^{-1} \mathrm{~cm}^{-1}$ at $230 \mathrm{~nm}$. Hydrogen peroxide solution (40 $\mathrm{mm}$ ) was prepared in phosphate buffer ( $\mathrm{pH} 7.4$ ). A total of $3.4 \mathrm{~mL}$ of different seaweed extracts (200-800 ppm) were added to $0.6 \mathrm{~mL}$ of hydrogen peroxide solution, and the absorbance was recorded at $230 \mathrm{~nm}$ after 10-min incubation against reagent blank solution. Butylated hydroxytoluene (BHT) was used as a reference compound. The percentage scavenging of hydrogen peroxide was calculated according to eqn (2).

Ferric reducing antioxidant power (FRAP) assay

Total antioxidant power of phenolic extracts of raw and processed seaweeds samples was measured using FRAP 
assay according to the method reported by Benzie \& Strain (1996) with some modifications. The reaction was performed in a microplate reader of 96-well plates (Powerwave, Biotek with software Gene 5) at a temperature of $37^{\circ} \mathrm{C}$. Preheated $100 \mu \mathrm{L}$ FRAP reagent at $37{ }^{\circ} \mathrm{C}(300 \mathrm{~mm}$ acetate buffer, $\mathrm{pH} \mathrm{3.6;10} \mathrm{mM} \mathrm{2,4,6-}$ tripyridyl-s-triazine (TPTZ) in $40 \mathrm{~mm} \mathrm{HCl}$ and $20 \mathrm{~mm}$ $\mathrm{FeCl}_{3} 6 \mathrm{H}_{2} \mathrm{O}$ in the ratio of $\left.10: 1: 1\right)$ was dispensed in each well with $50 \mu \mathrm{L}$ of samples or standard. The absorbance was read after $10 \mathrm{~min}$ at $593 \mathrm{~nm}$ with the help of microplate spectrophotometre. Trolox was used as a standard, and the results were expressed as $\mathrm{mg}$ of trolox equivalents/g extract (dw).

\section{Statistical analysis}

All the experiments were carried out in triplicate and replicated at least twice. Results are expressed as average \pm standard deviation (SD). Analysis of variance (ANOVA) and multiple comparisons (Fisher's least significant difference test) were used to find out the significant difference among various treatments using the STATGRAPHICS Centurion XV (StatPoint Technologies, Inc., Warrenton, VA, USA). Values of $P<0.05$ were considered as statistically significant.

\section{Results and discussion}

Effect of heat processing on the phytochemical constituents of seaweeds

\section{Total phenolic content}

Previous reports revealed that brown seaweed extracts, especially their polyphenols, have antioxidant activity (Kuda et al., 2005; Wang et al., 2009). Processing of any kind can alter the content, activity and bioavailability of bioactive compounds (Randhir et al., 2007). With this fact in mind, the present study aimed at investigating effect of hydrothermal processing on the bioactive compounds of brown Irish seaweeds. The TPC from methanolic extracts of raw brown seaweeds such as H. elongata, L. saccharina and L. digitata was $52.5 \pm 1.65,43.5 \pm 0.55$ and $35.8 \pm 1.30 \mathrm{mg} \mathrm{GAE} / \mathrm{g}$ and it increased by thermal processing at $95{ }^{\circ} \mathrm{C}$ by $64 \%, 75.6 \%$ and $89.9 \%$, respectively (Fig. 1a). Among the heat-treated samples, TPC significantly increased $(P<0.05)$ until $95^{\circ} \mathrm{C}$ and then was found to decrease continuously in all the tested species. Results also indicated that TPC was significantly higher in raw and heat-treated $\mathrm{H}$. elongata at $95^{\circ} \mathrm{C}$ when compared to the other two species. However, the increase in detectable TPC was more in L. digitata (1.9-fold) at $95{ }^{\circ} \mathrm{C}$. Heating beyond $95{ }^{\circ} \mathrm{C}$, resulted in a reduction in TPC and at $121^{\circ} \mathrm{C}$, the content dropped by $68-84 \%$ when compared to the raw species in all the tested seaweeds.

\section{Total flavonoid content}

Flavonoids are an important part of the diet because of their healthful effect on human nutrition as well as antioxidant activity like free radical scavenging and inhibition of hydrolytic and oxidative enzymes (Frankel, 1995). The effect of heat treatment on the flavonoids of brown seaweeds is shown in Fig. 1b. The TFC of raw $H$. elongata, L. saccharina and L. digitata were $18.3 \pm 1.36,29.5 \pm 2.08$ and $15.6 \pm 1.57 \mathrm{mg} \mathrm{QE} / \mathrm{g}$ and after heat treatment at $85{ }^{\circ} \mathrm{C}$, the TFC levels increased significantly $(P<0.05)$ by $171 \%, 59.7 \%$, and $230.1 \%$ respectively. Although the TFC increased significantly $(P<0.05)$ when the seaweeds were heated at $85^{\circ} \mathrm{C}$ and $95^{\circ} \mathrm{C}$, however the enhancement was more and statistically different at $85^{\circ} \mathrm{C}$ when compared to $95^{\circ} \mathrm{C}$ and raw seaweeds in all three species. Similar finding was also reported in case of steam-processed broccoli where TFC was increased by $295.5 \%$ (Roy et al., 2009). It is also concluded that raw L. saccharina had more TFC among all the tested species but after heating at $85^{\circ} \mathrm{C}$, the TFC increased more in L. digitata (3.3-fold) when compared to H. elongata (2.7-fold) and L. saccharina (1.6-fold). However, heating above $85^{\circ} \mathrm{C}$, the content was found to reduce continuously, and at $121{ }^{\circ} \mathrm{C}$, it was reduced almost 3-fold when compared to raw seaweeds. There was no significant difference $(P<0.05)$ observed in TFC of $H$. elongata with the other two species at $85{ }^{\circ} \mathrm{C}$.

\section{Total condensed tannin content}

Condensed tannins or proanthocyanidin, a polymer of flavonoids, are present in many plant species and are responsible for antioxidant capacity. The TTC in raw $H$. elongata, L. saccharina and L. digitata seaweed was $10.5 \pm 0.73,11.5 \pm 0.77$ and $8.1 \pm 0.73 \mathrm{mg} \mathrm{ChE} / \mathrm{g}$. However, after heating for $15 \mathrm{~min}$, the TTC significantly $(P<0.05)$ increased by $47.6 \%, 29.6 \%$ and $93.8 \%$ at $85{ }^{\circ} \mathrm{C}$ and $94.3 \%, 95.7 \%$ and $155.6 \%$ at $95{ }^{\circ} \mathrm{C}$, respectively (Fig. 1c). Results also indicated that raw and heattreated L. saccharina at $95^{\circ} \mathrm{C}$ had maximum amount of TTC when compared to the other two seaweeds. However, the effect of heat at $95{ }^{\circ} \mathrm{C}$ was more pronounced in $L$. digitata as the increase in TTC was higher (2.6-fold), when compared to L. saccharina (2-fold) and H. elongata (1.9-fold). It is also concluded that at $95^{\circ} \mathrm{C}$, no statistically significant difference was observed $(P>0.05)$ in TTC among all the tested species. Heating above $95^{\circ} \mathrm{C}$, the content deteriorated continuously reaching up to a third of the content of raw seaweeds by $121{ }^{\circ} \mathrm{C}$.

\section{Total sugar content}

The effect of heat on total sugar content was estimated, and results are shown in Fig. 1d. The TSC in $H$. elongata increased when heating at $85^{\circ} \mathrm{C}$ to a maximum of 4.3 -fold and then continuously decreased 

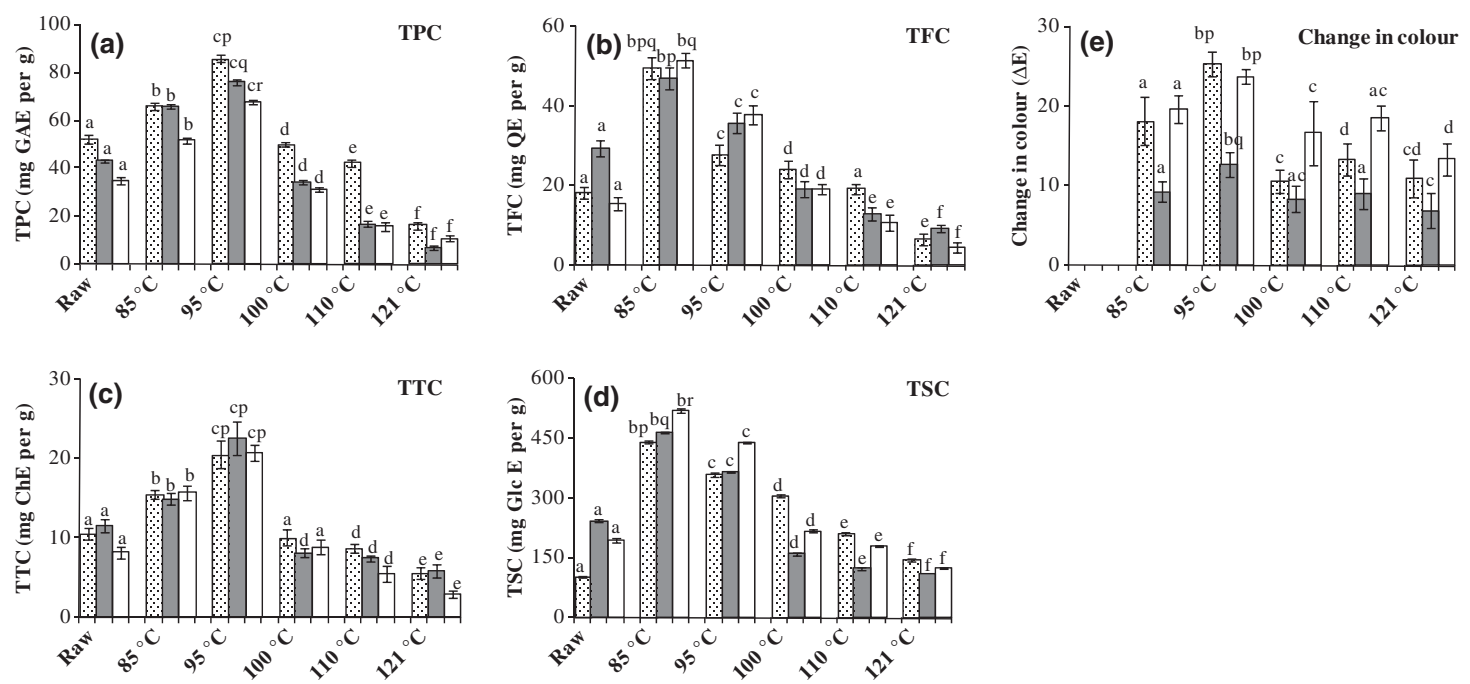

Figure 1 Phytochemical content and change in colour of raw and heat-processed Irish brown seaweeds extracts ( $\square$ : Himanthalia elongata; $\square$ : Laminaria saccharina; $\square:$ L. digitata).

but the amount was significantly higher even after 85 $121{ }^{\circ} \mathrm{C}$ when compared to raw seaweed. Similarly, in L. digitata and L. saccharina, the TSC increased at $85^{\circ} \mathrm{C}$ to a maximum of 2.7- and 1.9-fold and thereafter dropped continuously, while at $121{ }^{\circ} \mathrm{C}$ the percentage reduction was observed by $55.0 \%$ and $35.4 \%$, respectively. Results also indicated that the raw L. saccharina has maximum amount of TSC among all the raw species. However, after heating at $85^{\circ} \mathrm{C}$, the amount of total sugar was significantly higher $(P<0.05)$ in L. digitata $(520.6 \pm 4.83)$, while enhancement in TSC was maximum (4.3-fold) in $H$. elongata.

The changes in phytochemical content by hydrothermal processing, as indicated by the present results, could be attributed to the complete breakdown or modification of cellular components by heat. These phenolic compounds are usually present in bound states as conjugates with sugars, fatty acids or proteins. It could be anticipated that the disassociation of these complexes followed by some polymerisation of the phenolic contents may be responsible for the increased antioxidant capacity (Randhir et al., 2007). It can also be concluded that, after heat treatment, the increase in phenolic, flavonoid, sugar and tannin content may be because of the increased release of metabolites from the matrix which become more accessible during the extraction process (Roy et al., 2009). This indicates that thermal processing might produce changes in their extractability because of the disruption of the cell wall and cell membrane. Thus, bound polyphenols, flavonoids, sugars and tannins may be released more easily when compared to those in raw materials (Gawlik-Dziki, 2008; Roy et al., 2009). Jeong et al. (2004) and Choi et al. (2006) also reported the increase of total phenolic and flavonoids content in heated citrus peel and shiitake because of the breakdown of the matrix.

Heat treatment could deactivate endogenous oxidative enzymes that are responsible for the destruction of antioxidants. Therefore, the increased antioxidant content could be a result of the absence of enzymatic oxidation, generally caused by these enzymes, which subsequently prevent the loss of the antioxidant compounds in the heat-treated plant materials (Dewanto et al., 2002). It is reported that simple heat treatment could not cleave the covalently bound compounds but that far-infrared heat treatment could (Lee et al., 2003). This indicates that phenolic compounds of plants could be present in different bound states depending on the species.

\section{Effect of heat processing on colour of brown seaweeds}

The change in colour $(\Delta \mathrm{E})$ calculated from colour parameters $L^{*}, a^{*}$ and $b^{*}$ of raw and heat-treated seaweeds is illustrated in Fig. 1e. The smaller the values of $\Delta \mathrm{E}$, the closer the samples are in colour to the raw seaweeds. Values of $\Delta E$ between 0 and 0.2 indicate an imperceptible colour difference, $0.2-0.5$ for a very small difference, $0.5-1.5$ for a small difference, 1.5 3.0 for distinct, 3.0-6.0 for very distinct, $6.0-12.0$ for great and values $>12$ for a very great difference (Silva \& Silva, 1999). Results showed that heat treatment had a strong effect on change in colour; as the temperature increased, the value of $\Delta \mathrm{E}$ increased significantly $(P<0.05)$ in all the seaweeds species. The value of $\Delta \mathrm{E}$ was more than six at all temperatures which indicated a huge difference in colour after heat treatment $(P<0.05)$ in all the species. The effect of heat was more 
pronounced at $95^{\circ} \mathrm{C}$ as the value of $\Delta \mathrm{E}$ was maximum and statistically different $(P<0.05)$ from all the tested temperatures for each species. It was also observed that change in colour was not statistically different $(P<0.05)$ between $H$. elongata $(\Delta \mathrm{E} 25.4 \pm 1.55)$ and L. digitata $(\Delta \mathrm{E} 23.8 \pm 0.87)$ at $95^{\circ} \mathrm{C}$, while L. saccharina $(\Delta \mathrm{E} 12.6 \pm 1.56)$ had a significantly different value of $\Delta \mathrm{E}$ when compared to the other counterparts at the same temperature.

The increase in $\Delta \mathrm{E}$ value was reflected in high antioxidant content (as shown in Fig. 1) for a given temperature. In fact total phenol and total tannin content of raw and processed seaweeds were positively correlated with $\Delta \mathrm{E}$. Furthermore, the change in colour is a direct reflection of TTC and TPC which also increased significantly $(P<0.05)$ as temperature increased upto $95^{\circ} \mathrm{C}$ (Fig. 1c,e). The above-mentioned findings were confirmed by a high and significant $(P<0.05)$ positive correlation $\left(r^{2}\right.$ ranging from 0.901 to 0.947$)$ between the value of $\Delta \mathrm{E}$ and antioxidant content such as TTC in all the seaweeds.

Effect of heat processing on radical scavenging capacity of seaweeds

\section{$D P P H$ radical scavenging}

The free radical scavenging capacity of raw and processed seaweeds along with reference compounds, such as ascorbic acid and BHT, were determined by the DPPH radical and the results are shown in Fig 2a. The scavenging of $\mathrm{DPPH}^{\bullet}$ is caused by the donation of hydrogen by polyphenols, and the scavenging can be quantified by the change in colour from purple to yellow. A lower value of $\mathrm{EC}_{50}$ indicates a higher antioxidant capacity. The highest $\mathrm{DPPH}^{\bullet}$ scavenging was detected in raw $H$. elongata $\left(\mathrm{EC}_{50} 97.5 \pm 1.90 \mathrm{ppm}\right)$ followed by L. saccharina $\left(\mathrm{EC}_{50} 480.4 \pm 5.71 \mathrm{ppm}\right)$ and L. digitata $\left(\mathrm{EC}_{50} 619.5 \pm 8.58 \mathrm{ppm}\right)$. After heating at 95 ${ }^{\circ} \mathrm{C}$ for $15 \mathrm{~min}$, the antioxidant capacities increased in all the tested species. The $\mathrm{EC}_{50}$ value at the aforementioned temperature was $50.0 \pm 0.65,298.7 \pm 4.16$ and $332.8 \pm$ $3.58 \mathrm{ppm}$ for $H$. elongata, L. digitata and $L$. saccharina, respectively, which was significantly lower $(P<0.05)$ when compared to raw seaweeds. Results also indicated that raw L. saccharina has higher antioxidant capacity than $L$. digitata but after heat treatment, the activity was significantly higher in L. digitata. Among all the species treated at $95^{\circ} \mathrm{C}$, the $\mathrm{EC}_{50}$ of $H$. elongata was 6.6fold and 6-fold lower than L. saccharina and L. digitata. Even at the highest heating temperatures, the $\mathrm{EC}_{50}$ of $H$. elongata was significantly lower when compared to the lowest $\mathrm{EC}_{50}$ values of the other two species. The percentage reduction in $\mathrm{EC}_{50}$ values for all the seaweeds at $95{ }^{\circ} \mathrm{C}$ was $30.7-51.8 \%$. The $\mathrm{EC}_{50}$ values of all the processed seaweeds at $95^{\circ} \mathrm{C}$ were significantly higher $(P$ $<0.05)$ than ascorbic acid (36.9 \pm 0.54$)$ and BHT $(24.4$
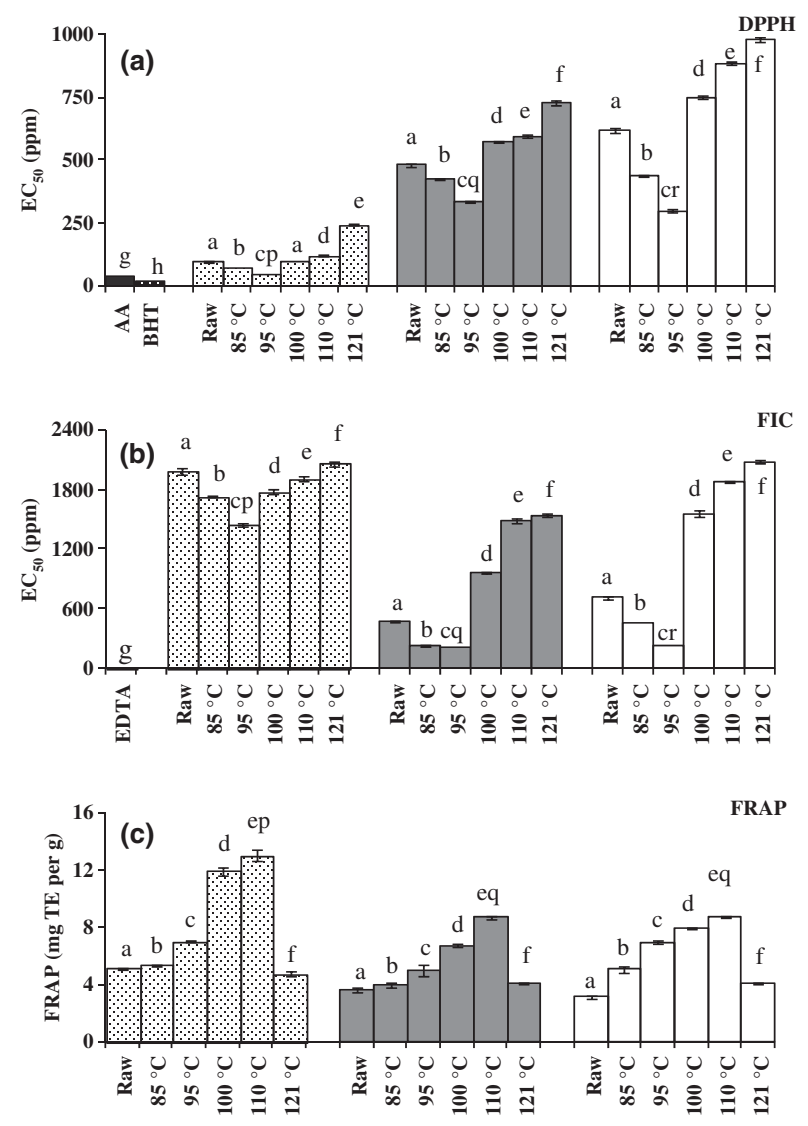

Figure 2 DPPH radical scavenging capacity $\left(\mathrm{EC}_{50}\right)$ (a) metal chelating ability $\left(\mathrm{EC}_{50}\right)(\mathrm{b})$ and Ferric reducing antioxidant power value $(\mathrm{mg}$ trolox equivalent/g) (c) of raw and heat-treated brown seaweeds ( $\square$ : Himanthalia elongata; $\square$ : Laminaria saccharina; $\square$ : L. digitata).

$\pm 0.28 \mathrm{ppm})$. The results obtained in the present study support the previous observation (Yoshiki et al., 2009) wherein heating seaweeds at $100-121{ }^{\circ} \mathrm{C}$ significantly enhanced the antioxidant activity by 1.4-2.4 times when compared to unprocessed seaweeds. A correlation analysis was carried out between phytochemical content and $\mathrm{DPPH}^{\bullet}$ scavenging capacities among all raw and heatprocessed seaweeds. In the case of $\mathrm{DPPH}^{\bullet}$ scavenging capacity, L. digitata showed high and significant correlation $(P<0.05)$ with phytochemical content $\left(r^{2}\right.$ ranging from 0.906 to 0.997 ). However, L. saccharina exhibited a statistical significant correlation with TPC and TTC, while $H$. elongata showed only a statistically significant correlation with TPC (data not shown).

\section{Metal ion chelating ability}

Metal ion chelating ability of raw and processed seaweeds along with EDTA (reference compound) was determined with the help of ferrozine- $\mathrm{Fe}^{2+}$ complex. Ferrozine has a tendency to form red-coloured complexes quantitatively, with ferrous ion but in the 
presence of other ion chelating agents, the complex formation is disrupted, resulting in a decrease in the red colour of the complex. Among all the tested seaweeds, unprocessed L. saccharina showed highest ferrous ion chelating ability followed by $L$. digitata and $H$. elongata (Fig. 2b). After heating at $95{ }^{\circ} \mathrm{C}$, the $\mathrm{EC}_{50}$ values for ferrous ion chelation reduced by $27 \%, 55.7 \%$ and $67.8 \%$ in $H$. elongata $\left(\mathrm{EC}_{50} 1450.0 \pm 21.36 \mathrm{ppm}\right)$, L. saccharina $\left(\mathrm{EC}_{50} 210.6 \pm 5.45 \mathrm{ppm}\right)$ and L. digitata $\left(\mathrm{EC}_{50} 231.2 \pm 2.58 \mathrm{ppm}\right)$, respectively. For Laminaria sp., heating beyond $95{ }^{\circ} \mathrm{C}$ resulted in continuous increase in the $\mathrm{EC}_{50}$ value, and at $121{ }^{\circ} \mathrm{C}$, it got enhanced by almost 3 -fold. However, for $H$. elongata, there was almost no change in the $\mathrm{EC}_{50}$ value between raw or processed at $121^{\circ} \mathrm{C}$. In comparison with EDTA, all the raw and heat-treated seaweeds species showed a weak ferrous ion chelating ability. EDTA exhibited excellent metal ion chelating ability at lowest concentration $\left(\mathrm{EC}_{50} 15.9 \pm 1.87 \mathrm{ppm}\right)$ tested.

\section{Ferric reducing antioxidant power}

Antioxidant power of raw and heat-processed extracts of seaweeds was estimated from their ability to reduce the colourless $\mathrm{Fe}^{+3}$-TPTZ complex to intense blue colour complex of $\mathrm{Fe}^{+2}-\mathrm{TPTZ}$. The reducing power indicates that the antioxidants present in the extracts have a tendency to donate electrons and can reduce the oxidised intermediates of the lipid peroxidation process, thereby acting as primary and secondary antioxidants (Yen \& Chen, 1995). The reducing power of raw and processed seaweed extracts varied markedly at different temperatures (Fig. 2c). Current work showed that raw $H$. elongata has more reducing ability than the other two studied seaweeds. After heating at various temperatures, the value of FRAP continued to increase significantly $(P<0.05)$ up to $110^{\circ} \mathrm{C}$ and then decreased when compared to raw seaweeds. At $110^{\circ} \mathrm{C}, \mathrm{H}$. elongata exhibited 2.6-fold enhancement followed by 2.4- and 2.8 -fold in L. saccharina and L. digitata. There was no statistical difference $(P<0.05)$ observed between the $L$. saccharina and L. digitata at the same temperature. However, at $121^{\circ} \mathrm{C}$, there was no reduction observed, and all the species showed almost similar FRAP value when compared to the respective raw seaweeds. Kuda et al. (2005) also demonstrated that the antioxidant power of Porphyra sp. increased after heating at $120{ }^{\circ} \mathrm{C}$.

\section{Lipid peroxidation in a haemoglobin-induced linoleic acid system}

Peroxyl radicals are formed by a direct reaction of oxygen with alkyl radicals, and these radicals attack biomolecules such as lipids to initiate free radical chain reactions and cause lipid peroxidation. The antioxidant effect of the extracts from raw, heat-processed seaweeds and BHT on the haemoglobin-catalysed peroxidation of linoleic acid was investigated, and the results are presented in Table 1. The lipid peroxidation capacity of raw H. elongata was highest when compared to L. saccharina and L. digitata. After heat treatment at various temperatures, it was observed that the effect of heat processing was more pronounced at $85{ }^{\circ} \mathrm{C}$ as the $\mathrm{EC}_{50}$ value reduced by $10.8 \%$ (H. elongata) to almost $30 \%$ in Laminaria sp. Heating beyond $100{ }^{\circ} \mathrm{C}$, all the extracts showed less scavenging capacity and at $121{ }^{\circ} \mathrm{C}$, the value of $\mathrm{EC}_{50}$ increased 1.4- to 1.8-fold, when compared to the unprocessed seaweeds. All the raw and processed seaweeds extracts exhibited less scavenging capacity than the reference antioxidant such as ascorbic acid $\left(\mathrm{EC}_{50} 94.2 \pm 0.76 \mathrm{ppm}\right)$.

\section{Hydrogen peroxide scavenging}

Hydrogen peroxide is only mildly reactive by itself but it can sometimes be toxic to cells or food system because it may give rise to hydroxyl radicals $\left(\mathrm{OH}^{\circ}\right)$ and singlet

Table $1 \mathrm{EC}_{50}$ values of hydrogen peroxide scavenging and lipid peroxidation for reference antioxidant compounds, raw and heat-processed Irish brown seaweeds extracts

\begin{tabular}{|c|c|c|c|c|c|c|}
\hline & Raw (ppm) & $85^{\circ} \mathrm{C}$ (ppm) & $95^{\circ} \mathrm{C}$ (ppm) & $100{ }^{\circ} \mathrm{C}(\mathrm{ppm})$ & $110^{\circ} \mathrm{C}(\mathrm{ppm})$ & $121^{\circ} \mathrm{C}(\mathrm{ppm})$ \\
\hline \multicolumn{7}{|c|}{ Hydrogen peroxide scavenging } \\
\hline Himanthalia elongata & $358.2 \pm 8.23^{\mathrm{a}}$ & $328.7 \pm 3.30^{\mathrm{b}}$ & $300.5 \pm 4.12^{\mathrm{cp}}$ & $305.3 \pm 5.35^{c}$ & $330.6 \pm 4.86^{\mathrm{b}}$ & $381.6 \pm 4.59^{d}$ \\
\hline Laminaria saccharina & $361.5 \pm 8.38^{\mathrm{a}}$ & $332.9 \pm 6.99^{\mathrm{b}}$ & $309.8 \pm 3.28^{\mathrm{cq}}$ & $323.9 \pm 5.33^{d}$ & $351.2 \pm 9.14^{\mathrm{e}}$ & $370.8 \pm 7.89^{f}$ \\
\hline L. digitata & $334.2 \pm 3.06^{\mathrm{a}}$ & $318.5 \pm 4.94^{\mathrm{b}}$ & $289.9 \pm 4.21^{\mathrm{cr}}$ & $330.0 \pm 5.67^{\mathrm{a}}$ & $345.7 \pm 4.21^{d}$ & $376.0 \pm 4.90^{\mathrm{e}}$ \\
\hline $\mathrm{BHT}^{\dagger}$ & $165.1 \pm 1.79^{g}$ & - & - & - & - & - \\
\hline \multicolumn{7}{|l|}{ Lipid peroxidation } \\
\hline H. elongata & $546.3 \pm 7.59^{a}$ & $487.4 \pm 3.30^{\mathrm{bp}}$ & $527.5 \pm 11.59^{c}$ & $694.2 \pm 13.91^{d}$ & $788.7 \pm 21.28^{\mathrm{e}}$ & $978.5 \pm 18.50^{f}$ \\
\hline L. saccharina & $721.5 \pm 24.57^{a}$ & $494.6 \pm 12.98^{\mathrm{bp}}$ & $705.6 \pm 15.94^{a}$ & $756.3 \pm 9.08^{c}$ & $943.9 \pm 16.02^{d}$ & $1007.3 \pm 8.24^{\mathrm{e}}$ \\
\hline L. digitata & $738.7 \pm 11.90^{\mathrm{a}}$ & $515.6 \pm 14.46^{\mathrm{bq}}$ & $753.1 \pm 12.62^{\mathrm{a}}$ & $945.3 \pm 15.59^{c}$ & $1028.3 \pm 7.02^{\mathrm{d}}$ & $1217.3 \pm 27.78^{\mathrm{e}}$ \\
\hline Ascorbic acid ${ }^{\dagger}$ & $94.2 \pm 0.76^{\mathrm{g}}$ & - & - & - & - & - \\
\hline
\end{tabular}

Data are expressed as mean $\pm \mathrm{SD}(n=6)$.

tReference antioxidant compound.

Letters $\left(^{a-g}\right)$ in a row are significantly different $(P<0.05)$ for various treatments for each individual species and the standard compound.

Letters $\left({ }^{\mathrm{p}-r}\right)$ in a column are significantly different $(P<0.05)$ for one temperature among the three species, for individual test. 
oxygen $\left({ }^{1} \mathrm{O}_{2}\right)$ by reacting with transition metals ions (Halliwell \& Gutteridge, 1999). The scavenging capacity of $\mathrm{H}_{2} \mathrm{O}_{2}$ by raw and heat-treated brown seaweeds along with reference antioxidant (BHT) are illustrated in Table 1. All the raw seaweeds extracts were capable of scavenging hydrogen peroxide in a concentrationdependant manner. At a concentration of $400 \mathrm{ppm}$ BHT, L. digitata, H. elongata and L. saccharina exhibited $100 \%, 60.0 \pm 0.37 \%, 56.1 \pm 2.37 \%$ and $55.8 \pm$ $1.85 \%$ scavenging capacity towards hydrogen peroxide, respectively (data not shown). With regard to $\mathrm{EC}_{50}$ values of hydrogen peroxide scavenging ability, L. digitata had the highest and statistically different $(P<$ $0.05)$ scavenging ability than the other two species, while there was no significant difference in scavenging ability observed in $H$. elongata and L. saccharina. After heating at $85,95,100$ and $110{ }^{\circ} \mathrm{C}$, the scavenging capacity increased when compared to raw but the highest and statistically significant $(P<0.05)$ scavenging ability was observed at $95^{\circ} \mathrm{C}$ in L. digitata followed by $H$. elongata and L. saccharina. The percentage reduction in $\mathrm{EC}_{50}$ values at the same temperature was around $15 \%$ in all the seaweeds. The percentage increase in $\mathrm{EC}_{50}$ values was only $2.6-12.5 \%$ in all the tested species when compared to raw. Thus, it can be interpreted that heating did not have much affect hydrogen peroxide scavenging capacity when compared to other antioxidant assays carried out in the present study. These results indicate that the compounds responsible for hydrogen peroxide scavenging capacity are almost heat stable and can be used as antioxidants in high temperature processed food products.

Previous studies have shown that phenolic compounds are the main contributors to the antioxidant capacity of various seaweeds followed by small amounts of other unknown compounds (Shibata et al., 2004). The ability of phenolic compounds to act as antioxidants is not only because of their tendency to donate hydrogen ions or electrons but also because of their stable radical intermediates, which prevents the oxidation of various food ingredients (Maillard et al., 1996). In the present study, heating plays a significant role in enhancing the phytochemical content and antioxidant capacity of Irish brown seaweeds. In some previous studies, heating vegetables has been shown to increase total antioxidant activity with the increase in TPC and TFC (Dewanto et al., 2002; Jeong et al., 2004; Choi et al., 2006). These reports give a strong support to the findings of the present study that heating could also enhance the antioxidant capacity in seaweeds.

\section{Conclusion}

This research work has revealed that Irish brown seaweeds are a good source of bioactive compounds.
They have potent antioxidant capacity which was significantly increased by heating. It is well known that natural constituents could be significantly lost during the heat processing because of the fact that most of the biologically active compounds are relatively thermolabile. However, in this study, heat treatment causes improved effect in the content and activities of naturally occurring antioxidants in seaweeds. Sometimes heating has the potential of producing novel compounds having antioxidant capacity through Maillard's reaction. These findings could provide new avenues for developing new nutraceutical foods based on seaweeds with particular considerations of processing conditions. The purification and identification of these bioactive compounds in brown seaweeds is currently undergoing.

\section{Acknowledgment}

The authors acknowledge funding from the Irish government under the Technological Sector Research Scheme (Strand III) of the National Development Plan.

\section{References}

Benzie, I.F.F. \& Strain, J.J. (1996). The ferric reducing ability of plasma (FRAP) as a measure of "antioxidant power": the FRAP assay. Analytical Biochemistry, 239, 70-76.

Campbell, R.. (2007). Seaweed a Source of Nutrition: Fact or Fiction? Presentation. Irish Plant Scientists Association.

Chandini, S.K., Ganesan, P. \& Bhaskar, N. (2008). In vitro antioxidant activities of three selected brown seaweeds of India. Food Chemistry, 107, 707-713.

Choi, Y., Lee, S.M., Chun, J., Lee, H.B. \& Lee, J. (2006). Influence of heat treatment on the antioxidant activities and polyphenolic compounds of Shiitake (Lentinus edodes) mushroom. Food Chemistry, 99, 381-387.

Decker, E.A. \& Welch, B. (1990). Role of ferritin as a lipid oxidation catalyst in muscle food. Journal of Agricultural and Food Chemistry, 38, 674-677.

Dewanto, V., Wu, X., Adom, K. \& Liu, R. (2002). Thermal processing enhances the nutritional value of tomatoes by increasing the total antioxidant activity. Journal of Agricultural and Food Chemistry, 50, $3010-3014$

Diplock, A.T., Aggett, P.J., Ashwell, M., Bornet, F., Fern, E.B. \& Roberfroid, M.B. (1999). Scientific concepts of functional foods in Europe: consensus document. British Journal of Nutrition, 81, $1-27$.

Dubois, M., Gilles, K.A., Hamilton, J.K., Rebers, P.A. \& Smith, F. (1956). Colorimetric method for determination of sugars and related substances. Analytical Chemistry, 28, 350-356.

Finkel, T. \& Holbrook, N.J. (2000). Oxidant, oxidative stress and the biology of ageing. Nature, 408, 239-247.

Frankel, E.N. (1995). Antioxidants in lipid foods and their impact a food quality. Food Chemistry, 57, 51-55.

Gawlik-Dziki, U. (2008). Effect of hydrothermal treatment on the antioxidant properties of broccoli (Brassica oleracea var. botrytis italica) florets. Food Chemistry, 109, 393-401.

Gupta, S., Rajauria, G. \& Abu-Ghannam, N. (2010). Study of the microbial diversity and antimicrobial properties of Irish edible brown seaweeds. International Journal of Food Science and Technology, 45, 482-489.

Halliwell, B. \& Gutteridge, J.M. (1999). Free Radicals in Biology and Medicine. Oxford: Oxford University Press. 
Jeong, S.M., Kim, S.Y., Kim, D.R., Jo, S.C., Nam, K.C. \& Ahn, D.U. (2004). Effect of heat treatment on the antioxidant activity of extracts from citrus peels. Journal of Agricultural and Food Chemistry, 52, 3389-3393.

Kuda, T., Tsunekawa, M., Goto, H. \& Araki, Y. (2005). Antioxidant properties of four edible algae harvested in the Noto Peninsula, Japan. Journal of Food Composition and Analysis, 18, 625-633.

Lee, S.C., Kim, J.H., Jeong, S.M. et al. (2003). Effect of far-infrared radiation on the antioxidant activity of rice hulls. Journal of Agricultural and Food Chemistry, 51, 4400-4403.

Liu, S.C., Lin, J.T., Wang, C.K., Chen, H.Y. \& Yang, D.J. (2009). Antioxidant properties of various solvent extracts from lychee (Litchi chinenesis Sonn.) flowers. Food Chemistry, 114, 577-581.

MacArtain, P., Gill, C.I.R., Brookes, M., Campbell, R. \& Rowland, I.R. (2007). Nutritional value of edible seaweeds. Nutrition Reviews, 65, 535-543.

Maillard, M.N., Soum, M.H., Boivia, P. \& Berset, C. (1996). Antioxidant activity of barley and malt: relationship with phenolic content. Lebensmittel-Wissenschaft and Technologie, 3, 238-244.

Morrissey, J, Kraan, S. \& Guiry, M.D. (2001). A Guide to Commercially Important Seaweeds on the Irish Coast. Pp. 15-40. Dublin: Bord Iascaigh Mhara/Irish Fisheries Board.

Plaza, M., Cifuentes, A. \& Ibánez, E. (2008). In the search of new functional food ingredients from algae. Trends in Food Science \& Technology, 19, 31-39.

Randhir, R., Kwon, Y.I., Lin, Y.T. \& Shetty, K. (2007). ffect of thermal processing on the phenolic associated health-relevant functionality of selected legume sprouts and seedlings. Journal of Food Biochemistry, 33, 89-112.

Roy, M.K., Juneja, L.R., Isobe, S. \& Tsushida, T. (2009). Steam processed broccoli (Brassica oleracea) has higher antioxidant activity in chemical and cellular assay systems. Food Chemistry, 114, 263-269.

Ruch, R.J., Cheng, S.J. \& Klaunig, J.E. (1989). Prevention of cytotoxicity and inhibition of intracellular communication by antioxidant catechins isolated from Chinese green tea. Carcinogenesis, 10, 1003-1008.

Shibata, T., Kawaguchi, S., Hama, Y., Inagaki, M., Yamaguchi, K. \& Nakamura, T. (2004). Local and chemical distribution of phlorotannins in brown algae. Journal of Applied Phycology, 16, 291-296.

Silva, F.M. \& Silva, C.L.M. (1999). Colour changes in thermally processed cupuaçu (Theobroma grandiflorum) puree: critical times and kinetics modeling. International Journal of Food Science and Technology, 34, 87-94.

Taga, M.S., Miller, E.E. \& Pratt, D.E. (1984). Chia seeds as a source of natural lipid antioxidants. Journal of the American Oil Chemists Society, 61, 928-931.

Wang, T., Jónsdóttir, R. \& Ólafsdóttir, G. (2009). Total phenolic compounds, radical scavenging and metal chelation of extracts from Icelandic seaweeds. Food Chemistry, 116, 240-248.

Yen, G.C. \& Chen, H.Y. (1995). Antioxidant activity of various tea extracts in relation to their antimutagenecity. Journal of Agricultural and Food Chemistry, 43, 27-37.

Yoshiki, M., Tsuge, K., Tsuruta, Y. et al. (2009). Production of new antioxidant compound from mycosporine-like amino acid, porphyra-334 by heat treatment. Food Chemistry, 113, 1127-1132. 